\title{
Embodying Love in the Inner City : Undoing Injustice through Intentional Neighboring
}

Katherine Hankins, Andy Walter and Traci Dahl

\section{(2) OpenEdition}

\section{Journals}

Electronic version

URL: https://journals.openedition.org/transatlantica/9427

DOI: $10.4000 /$ transatlantica.9427

ISSN: 1765-2766

\section{Publisher}

Association française d'Etudes Américaines (AFEA)

\section{Electronic reference}

Katherine Hankins, Andy Walter and Traci Dahl, "Embodying Love in the Inner City: Undoing Injustice through Intentional Neighboring", Transatlantica [Online], 1 | 2017, Online since 19 November 2018, connection on 24 May 2021. URL: http://journals.openedition.org/transatlantica/9427 ; DOI: https:// doi.org/10.4000/transatlantica.9427

This text was automatically generated on 24 May 2021.

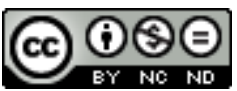

Transatlantica - Revue d'études américaines est mise à disposition selon les termes de la licence Creative Commons Attribution - Pas d'Utilisation Commerciale - Pas de Modification 4.0 International. 


\title{
Embodying Love in the Inner City : Undoing Injustice through Intentional Neighboring
}

\author{
Katherine Hankins, Andy Walter and Traci Dahl
}

\section{Introduction}

1 On February 26, 2014, Peter Kageyama, an American author and community development consultant, gave the keynote address at the annual meeting of the Midtown Alliance, a successful business improvement district in Atlanta, Georgia, USA. Kageyama's talk drew from his recently published book titled For the Love of Cities. Love, he writes in the book, "is the most powerful tool ever unleashed in the development of our communities" (Kageyama 214). Speaking to a large audience of business and municipal leaders, planners, high-level bankers, and real estate developers, he explained that when people love their city, they engage with it, participate in it, champion it, fight for it, protect it, invest in it, remain loyal to it, and "do extraordinary things for it." In other words, people who love their cities are eager to play the role of producer and "co-creator," rather than that of spectator or consumer. Given this, Kageyama asked, as he does in the book, “Why aren't more people talking about love and how to increase love in our communities?" His own answer to this question is to create a city worth loving. Such a city is one that is "fun," "interesting," "beautiful," "whimsical" and "creative," because it features particular elements that Kageyama refers to as "love notes," including "third spaces" (neither work nor home, e.g. coffee shops), specialty foods and/or drinks, environmental sustainability projects, local philanthropic grant providers, independent bookstores, alternative media, public art, an organic nickname (Detroit as "Motor City"), and design elements that are "friendly" for young people, families, bicycle riders, pedestrians, and pets. These "love notes" allow cash-strapped cities to harness the "development capacity" of their 
citizens by attracting them onto the urban stage. "[T]hey need to be seduced!" he declares (199).

Elsewhere in Atlanta, in a starkly different setting only a mile-and-a-half west of the lavish Fox Theater where Kageyama delivered his address, questions about love and urban communities were also being asked. From her home in one of Atlanta's most disinvested, neglected neighborhoods, "Sarah" asked "How can we begin to offer love to neighborhoods that aren't loved and to people who aren't loved?" Sarah, like thousands of other middle-class Christians across the United States and beyond, had been called by her faith and specifically God's command to "love your neighbor as yourself" to move to a place where she could live in solidarity with the poor and disenfranchised. In doing so, Sarah and these others constitute a broader movement known as Christian community development, whose aim is to create a space of reconfigured social relations called beloved community by Dr. Martin Luther King, Jr. To Dr. King beloved community signified a reconciliation between oppressed and oppressor, and redemption for both, meaning freedom from their prior conditions. Beloved community "is not self-generating," he cautioned (Marsh, 2005, 2), but comes about through the "love method," a forgiving, understanding posture and patient, creative, unrelenting and embodied struggle. As with Kageyama's call to create "lovable cities," love serves to animate human bodies socially, leading them onto the urban stage to participate in making the city.

3 The broad purpose of this paper is to consider the role of love in city making. Specifically, we examine the case of Christian community development with a particular focus on "intentional neighboring," the practice engaged in by Sarah and by others like her in cities across the United States. What we are interested in is how Christian community developers, and specifically intentional neighbors, operationalize love as an approach to city making and, to be more precise, to social and spatial inequalities in urban neighborhoods. The paper is motivated by a contrast we have observed between different meanings and uses of love in city-making and the concomitant political subjectivities that different kinds of love inspire.

As with all places, cities are produced by a variety of actors and flows operating according to a range of motivations and logics, at and across multiple scales, both near and far, as well as within and beyond any formal or material boundaries of the city (Massey, 2005). In urban geography literature, "city makers," while not typically defined as such, have included actors in the political economy such as urban regimes (Stone, 1989), real estate developers (Palm, 1976), urban "imagineers" (Rutheiser, 1996 ; Kageyama, 2011), planners, and housing authorities (Vale, 2013; Oakley and Fraser, 2016), and, at the more local scale, community-based organizations (Lepofsky and Fraser, 2003 ; Defilippis, 2004 ; Defilippis, et al. 2010), and neighborhood activists (Fraser, 2004 ; Hankins, 2007 ; Martin 2002a, 2002b, 2003 ; Martin et al. 2007 ; Pierce et al. 2011). We add to this list-and explore the role of-intentional neighbors as agents of urban social change in their everyday actions (see Hankins, 2017) and highlight the philosophy and spatial practices of embodied love through the case study of the Mission Year program, a Christian community development organization that places young adults in high-poverty inner city neighborhoods to live out their faith and to learn from the city. Through analysis of the curriculum materials and interviews with Mission Year staff and participants about their experiences in the inner city, we 
suggest that the embodied love intentional neighbors practice creates new political subjectivities and possibilities for creating not loveable cities but loving cities.

\section{Love as a Method of City-Making}

Philosophers and social scholars have debated the various meanings and practices of love, conventionally distinguishing three types : eros, philia, and agape. The essence of eros love is attraction, "being in the grip of something, drawn to it, attracted to it" (Wolterstorff, 2011, 37). Philia is the love of attachment, friendship, and reciprocity. As King put it, philia love is what exists when "you like a person because that person likes you" (King, 1957). In addition to the romantic love of eros and the "brotherly love" or philia, agape love consists in benevolence, expressed when one seeks the flourishing of another as an end unto itself. Agape is often referred to as "neighbor love" in that selfless love is what is asked of Christians by the biblical injunction to "love your neighbor." As Wolterstorff $(2011,77)$ recounts, the writer and scholar C.S. Lewis described agape as "love as benevolence, love that seeks to promote the good of a person as an end in itself," and to King agape means "goodwill for all... [and seeking] nothing in return" (King, 1957).

6 In a recent article, Zitcer and Lake consider the role of love in urban planning, turning to Hannah Arendt (1958). On the one hand, Arendt largely dismisses notions of love as private and distinct from the necessary publicness of the political and, thus, planning. On the other hand, Arendt provides an opening to consider the social relationships and practices motivated by different sorts of love and their implications for urban change through planning practice. Publicity, she argued, "is an essential condition for politics because, in contrast to the invisibility of the private realm, 'everything that appears in public can be seen and heard by everybody' and thus to be political is to be public" (Arendt, 1958, 50). Given this, Arendt rejected eros love as distracting and private and therefore necessarily unpolitical. Furthermore, she identified pity, fraternity, and compassion as expressions of love that are unpolitical or even antipolitical (Chiba, 1995). For example, as Chiba explains, Arendt was skeptical that the political principle of solidarity (with, for example, "a community of interest with the oppressed and exploited" (Arendt, 1965, 88-89)) is compatible with notions of sentimental love. For her, the political world is harmed by sentimental love that is prone to emotional bias and passionate outburst and therefore works against the reasoned and dispassionate commitments required. Arendt also arrived at a position that was critical of agape, or Christian neighborly love, arguing that it was "like romantic or affectionate love, worldless and incapable of founding a public realm of its own" (Arendt, 1958, 53). According to Arendt, it is only in friendship love, philia, that a possibility for politics resides because this sort of love is "a companionship with others as equal partners in a community common to them" (Chiba 518). In Arendt's writings, "friendship presents itself as a closest resemblance or image to the public activity of citizens, characteristics of which can consist in spontaneity, discussion, speech, common deliberation, persuasion, cooperation, or the absence of hierarchy" (Chiba 519). Friendship is not based on likeness or homogeneity of friends "but rather on the recognition of, and due respect for, their differences and heterogeneity" (521). Applying this to urban planning, Zitcer and Lake anticipate a practice of city-making by planners that is less distanced and abstract. Philia should produce a mutually respectful back-and-forth 
among differently situated subjects, yielding projects informed by "“a collective social wisdom not available from any one position"' (Young 76, quoted in Zitcer and Lake 609). In urban planning, therefore, brotherly love can close social distance and produce a shared commitment to particular urban problems.

7 For Kageyama, who writes in a popular vein that would include planners as well as other policymakers, elected officials, and civil society actors, the city serves as the object of love. He yearns for cities that allure their inhabitants, cities that are sufficiently fun, friendly, and whimsical that people will fall "in love" with them (Kageyama 5). What he describes in his book seems to be eros love in city making. But to what end, and why? The answer is found in Kageyama's embrace of Richard Florida's notion that "successful" cities are those that can attract and retain the "creative class." The creative class refers to workers in knowledge-based economies, from engineering, medicine, and law to education, media, arts and design. Kageyama, who named his own urban-focused nonprofit organization Creative Tampa Bay, is not alone in his enthusiasm for this approach to community development, as hundreds of elected officials and policymakers across the United States and beyond have been inspired and guided by Florida's "creative class" idea, reflecting a secular shift toward a neoliberal urban governance regime with its emphasis on providing space(s) for elite consumption (Brenner and Theodore, 2002). Kageyama's contribution is the highlighting of "emotional engagement" (love) as a means to that end. Moreover, as with other Florida-inspired "creative" approaches, Kageyama's neglects social structures and distributional concerns (McCann, 2007). His "love method," to use King's phrase, is apolitical and indifferent to questions of justice, such as those that have concerned urban scholars in recent decades, including Fainstein (2010), Soja (2010), and Marcuse et al (2009), and urban activists, such as Hern (2016). In contrast, the love mobilized by Sarah, the intentional neighbor, is different than Kageyama's. The city is not an object of love but the product of it. Love is the expression of her colleagues and her activities in the city as well as their goal, as they aim to bring into being Dr. Martin Luther King, Jr's notion of beloved community. In other words, love requires embodied practice for the purpose of undoing injustice. As she explained, she could not be "involved with social justice from afar and still be comfortable." The Christian call to love her neighbor compelled her to personally see and experience "the circumstance we are living in... [A] society that is unjust all over the place... [and to understand] how can we begin to make some changes?" (interview with Sarah, 2012).

8 The form of city-making that Sarah and others are engaged in is motivated, guided, and sustained explicitly by the notion of beloved community-or agapic love (Marsh and Perkins, 2009). Arendt dismissed agape as the basis for politics-which inheres in urban change-because its unconditional universalism to love all equally and without judgment renders it, like eros, "worldless," that is, unconcerned with historically and geographically contingent social circumstances. We suggest that the practice of "intentional neighboring" challenges this conclusion. Intentional neighbors engage in a form of city-making that occurs through what Hankins calls the "quiet politics of the everyday." (Hankins, 2017, 2) As a force of urban change, "quiet politics" refers to the cumulative decisions made by individual urban subjects, particularly those privileged by structures of race and class. As Hankins explains, it is

[q]uiet in that we are talking about decision-making, which is inaudible but can have important consequences for a process of creative democracy to thrive or to be extinguished. [...] [And it is p]olitics because it is about rejecting hegemonic norms 
of middle-classness or working classness and acting differently or living differently or developing relationships and understandings and conversations across class and race and gender and sexuality. Quiet politics are about pushing back against behaviors and institutions that reproduce oppression in everyday ways, that cumulatively, together, in fits and starts can create the conditions for [urban change]. (Hankins, 2017, 504)

Intentional neighbors like "Sarah" in Atlanta who are self-aware of their privilege seek to "act differently" in the world. Christian community development writers, including the founder of the movement, John Perkins, use words such as "subversive" and "counter-cultural" to describe intentional neighboring because these individuals are stepping outside of the social roles and urban spaces that would be expected of them due to their social position and identity. As Perkins explains the practice, it is a refusal to "let the world define us [and keep us in our place] to the point that we don't [...] make community possible across racial and economic lines" (Perkins, and Marsh, 2009, 42). Thus, we argue, the social practice of intentional neighboring, motivated by agapic love, is hardly "worldless," to use Arendt's term, and is therefore politically effective (as in a grounded social force, if not "successful," however defined).

10 Some philosophers and theologians have debated the social application of agape, particularly the question of the relationship between love and justice. The philosopher and theologian Nicholas Wolterstorff identifies three positions. First, the position of classical agapism, developed by writers including Kierkegaard and Nygren, holds the view that loving agapically is incompatible with seeking justice because the latter requires making a judgment about the recipient of love. Because God's love is not motivated by consideration of a person's social circumstance or recognition of her worth, it must therefore remain "blind and deaf to justice and injustice" (Wolterstorff, 2011, 42). This position most closely resembles the "worldless" version in Arendt's account. Niebuhr offers a second position. He agrees that God's love is blind-that is, given equally and without question-but asks what we are to do in a world of friction and disharmony that periodically threatens the survival of human communities and the well-being of individuals. "What's called for in cases of conflict is justice, not agapic love," as Wolterstorff puts it $(2011,66)$. Faced with this reality, addressing significant conflict may necessitate the recognition of rights, coercion, and social struggle, all of which "represent something less than the ideal of love" (quoted in Wolterstorff, 2011, 67). Thus, whereas love rules out justice in classical agapism, in Niebuhr's account, love is constrained, at times, by justice. And here again, Arendt's pessimism about the political possibilities of agape seem confirmed. Wolterstorff offers a third position that he calls "care-agapism." This is a love that incorporates justice in that in seeking to promote a person's well-being, consideration is given to whether her rights are secure and honored. As he explains, love that pays no attention to a person's rights (this he calls "benevolence") is a love that would eventually perpetuate injustice and this would be a "malformed love" (Wolterstorff, 2011, 72). Care love, in contrast, is that which incorporates doing what justice requires. In practice this means being alert to understanding "actual human needs" in social contexts. This, we suggest, presents a worldly version of agape and a method for urban change.

11 An endeavor to enact care love, we argue, is evident in writings and practices of Christian community development, most notably, in the "three-R" strategy of Christian community development, articulated by Civil Rights veteran John Perkins $(1996,2007)$. The first $\mathrm{R}$ involves the embodied self-relocation to places of social marginality to live 
among the poor. This relocation is a key part of the witness of Christians to live as Jesus did, in the flesh, in places where there is need. ${ }^{1}$ This relocation practice involves a redistribution of resources, constituting the second R of care agapism. Christians are called to share their gifts, whether political clout, money, or material goods, with those in need. And, importantly for John Perkins, the third R involves racial reconciliation, or engaging in the difficult process of reaching across lines of race and class to recognize and mend the fissures and pain of a racialized society (Perkins, 1996). This is not achieved through "social mix" or mere diversity in place but through attempting to build mutually respectful relationships across racial and cultural differences. Reconciliation inevitably requires addressing exploitative economic relations, as accumulated inequalities in wealth and material resources present significant barriers among social groups. Thus, the three-R's represent an intertwined sociospatial agenda that requires embodied praxis to love and seek justice for neighbors in the city.

Underlying the three-R strategy is the social (and spatial) application of agape love with the intention to form beloved community, which for Dr. Martin Luther King, Jr. was a social, theological and geographical method to bring about justice and achieve social change. More specifically, it makes social change effective by cultivating human agency, encouraging individuals and groups to stand up and oppose an unjust system of oppressors and oppression, loving oppressors through divine agape love, and converting one's enemy into a collaborator to build beloved community (King, 1967; Inwood, 2009). Importantly, we suggest, this is seen as a process of developing a concern with the political-an emergent care-agapism not to be dismissed as private or antipolitical. In what follows, we examine the Mission Year program, a Christian community development organization that recruits and guides young adults in their 20 s and 30s to move into inner-city neighborhoods that have suffered systemic disinvestment and spend a year encountering poverty and difference in the city, and we ask how their conceptualizations of justice and injustice emerge and change as a result of their embodiment of (care agape) love in the city.

\section{Case study : Mission Year}

13 Mission Year is an independent organization and a member of the Christian Community Development Association, which is an international organization of members that range from churches to faith-based organizations to individuals who are committed to "reclaiming and restoring under-resourced communities" (CCDA website, 2018). Mission Year organizers explicitly articulate the purpose of the organization as “...see[ing] people fall in love with Jesus and the city, come alive in their gifts and purpose, build beloved community across all dividing lines, and become advocates for God's justice in our neighborhood and world" ("Who We Are," 2017). The organization coordinates placing teams of six to seven 18-30 year-olds who have identified as Christians in a house in an inner-city neighborhood in one of several cities across the country. As of 2018, there are Mission Year houses in Houston, Chicago, and Philadelphia, but the program has operated in cities such as Oakland, California, and, for over a decade in various neighborhoods in Atlanta, Georgia. Mission Year recruiters travel the United States speaking or setting up tables at churches, colleges, and various events to recruit participants into the program. The organizers assist each new recruit in raising approximately $\$ 12,000$ from private sources, such as their local churches, to 
participate in the program, which runs each year from September through July. A staff member shared with us that the organization does not want money to hinder people from participating because Mission Year does not want to be "a club for privileged kids who can afford to do it" and "because everyone needs to learn [social justice] principles, we want to make it open for people to learn them" (interview with Shelley, 2012).

Interviews with Mission Year staff members revealed the expectations of participants, "rules" that are designed to implement the three-R philosophy in their program. During the eleven-month period, Mission Year team members must (1) relocate to an inner-city neighborhood, (2) host community dinners every Saturday night, where they invite their neighbors to eat with them, (3) volunteer 25-30 hours between Monday and Thursday at a nearby non-profit organization (4) have "family" nights building Christian community with other Mission Year teammates, (5) complete a curriculum including academic and popular materials, including books and documentaries and listening to guest speakers selected by the staff, (6) refrain from watching any television, (7) have limited access to other electronic media, cell phones and their home social network, (8) use public transportation (they are permitted the use of a bike, but no car), (9) spend time each morning in solitude and prayer and (6) live minimally or as it is often termed "living in simplicity" or "living simply." Participants are given an allotment of $\$ 70$ per month for women and $\$ 60$ per month for men for personal items and services, such as laundry, feminine products, shampoo, or taking a neighbor to the movies. ${ }^{2}$ Beyond this allotment, each participant receives $\$ 17$ a week for food, which most teams pool together to purchase food for the whole Mission Year house.

Mission Year partners with organizations that are already working in the neighborhoods, such as senior centers or youth advocacy organizations, providing them with their participants' labor for a year and, in return, receiving a donation from the organization. This is a key determinant of the neighborhoods within which Mission Year operates. According to staff members, Mission Year "city leaders" look for a community of need, where organizations are already functioning to address existing concerns. Equally important for city leaders selecting a neighborhood is the existence of a neighborhood church that is willing to partner with Mission Year. The team members become a part of that church community and take on responsibilities within the church.

Thus, the goal of the program is twofold. The leaders of Mission Year want to provide full-time volunteers to assist in local service organizations i I n what they term "underresourced" communities while, also, teaching participants the three-R philosophy or "principles" of Christian community development via their curriculum. Participants learn about numerous issues surrounding intentional neighboring while simultaneously experiencing them in the neighborhoods where they live. In this paper, we highlight the curriculum and the participant experiences from two Mission Year houses that operated in the inner-city Atlanta neighborhoods of English Avenue and Polar Rock during the 2011-2012 academic year. We conducted a total of 18 semistructured interviews with active participants and past participants (during the 2011-2012 year) (see table 1). Ten of these were new Mission Year team members, with whom we spoke during the fifth month of their Mission Year experience. Six were past team members, one of whom, Shelley, was a Mission Year employee, who gave us extensive information about the organization, reflecting on the six-plus years she had 
been employed as a city leader following her own Mission Year experience. In addition we spoke to two other staff members, who were also past participants, whom we call Sue and Bart, who mainly focused their discussion on the organization.

17 At the time of our interviews, the neighborhoods were experiencing intense disinvestment, following the Subprime Mortgage crisis of 2008, which further devastated these neighborhoods. For example, the house in the English Avenue neighborhood sat on a city block that was three-quarters vacant. Likewise, the Mission Year house in the Polar Rock neighborhood was surrounded by streets where vacancy rates exceeded $50 \%$, according to 2010 Census data (and confirmed by observation).

Table 1 : List of interview participants

\begin{tabular}{|l|l|l|l|}
\hline Pseudonym & Gender & Ethnicity & Description of home neighborhood ${ }^{3}$ \\
\hline \multicolumn{2}{|l|}{ Past members } & \multicolumn{1}{|l|}{} \\
\hline Joe & M & White & White, middle-class suburb \\
\hline Lisa & F & White & N/A \\
\hline Debbie & F & White & White, middle-class small town \\
\hline Sharon & F & White & White, middle-class suburb \\
\hline Lori & F & White & White, middle-class farming town \\
\hline Shelley (s) & F & White & White, lower-income town \\
\hline New Members as of 2011 & White & Rural \\
\hline Wendy & F & Asian & Diverse suburb \\
\hline James & M & White & White, middle-class inner suburb \\
\hline Lillian & F & White & White, small town \\
\hline Anne & F & Latina & Middle-class, outer suburb \\
\hline Sarah & M & White & White, rural town \\
\hline Cheryl & F & Latina & Diverse city neighborhood \\
\hline Felle & F & Asian & Lower to middle-class city neighborhood \\
\hline
\end{tabular}


Notes:

(s)-indicates Mission Year staff member

$\mathrm{N} / \mathrm{A}$-interviewee did not reveal the information

The bulk of the Mission Year Curriculum consists of books. Our textual data consisted of 13 books and the documentary data included two films:

Restoring At-Risk Communities, edited John Perkins, 1996

The Way of the Heart, Henri Nouwen, 2003

Why are all the Black Kids Sitting Together in the Cafeteria? Beverly Daniel Tatum, 2017[1997]

Community and Growth (chapter one), Jean Vanier, 1989

The Next Evangelicalism, Soong-Chan Rah, 2009

What Would Jesus Buy? (documentary), 2007)

The Power of Race (PBS documentary), 2003)

The Ragamuffin Gospel, Brennan Manning, 2005

Jesus and the Disinherited, Howard Thurman, 1996

The Secret of the Christian Life (article), John Alexander, 1993

A Different Drum (chapter two), M. Scott Peck, 1998

Flat Broke: Women in the Age of Welfare Reform, Sharon Hays, 2004

Simple Spirituality: Learning to See God in a Broken World, Chris Heuertz and Shane Claiborne, 2008

Living in Color, Randy Woodley, 2004

Sidewalks in the Kingdom, Eric Jacobsen, 2003

The curriculum is tailored by the local staff members each year, based on feedback from prior years and by the focus issues the staff determine. As Shelley explained, each city director has some latitude to choose the curriculum, but "each trimester we try to hit upon race and ethnicity, a social justice issue [...] so one trimester we'll do, like, women in the welfare system, and we look at spirituality. So those are the three main things : race, a social justice-type of issue and then spirituality or spiritual formation." Running through the entire curriculum and staff interviews is the call for Christians to live the way Jesus did, according to his example and his teachings, which involves living in community, living among the poor, and engaging in the three ' $R$ 's of Christian community development. And in the interpretation of Mission Year proponents, and Christian community development more broadly, this is a call to live in the city. The city itself, or the experience of embodied, everyday life in high-poverty neighborhoods, provides participants with their most important lessons, and, as we suggest below, the emergence of new political subjectivities.

This research is part of a broader study on the place-making practices of Christian community development organizations and individuals, of which Mission Year is one of hundreds of organizations-and one of the few-that explicitly focuses on the training and exposure of young adult Christians to the American inner city. Beyond the scope of this research is the ways in which indigenous residents understand and react to intentional neighbors, although many of the Mission Year participants and intentional neighbors we interviewed between 2010 and 2015 were eager to understand the degree to which their efforts were "working." We feel strongly that this question is largely unknowable, given the range of possibilities and desired outcomes among intentional neighbors and the residents in whose neighborhoods they move. For example, for one participant, a "successful" Mission Year experience might be where one resident learns 
about the power of Christianity, whereas for another, it may be the improvement in the material well-being of an indigenous household or the development of a reciprocal friendship.

The more specific research questions of the Mission Year case study involved unpacking the notions of social justice that the Mission Year curriculum, based on notions of beloved community, sought to impart and, more importantly, the ways in which the participants articulated how their own understanding of social (in)justice changed because of their experience in the program and in their Atlanta neighborhood. While we acknowledge that many of the practices of intentional neighbors and Mission Year participants may be seen as quasi-colonial "do-gooder" activities, our interest is in the transformative potential of intentional neighbors' political subjectivities. Specifically, among those who come into this as relatively privileged and culturally "middle class," can the "love method" defined by the 3-Rs lead to encounters and understandings that provide the basis for new cross-class (or other group) alliances and urban practices (Lawson and Elwood, 2018)? If structural and relational understandings of social and spatial injustice are revealed in the potentially extractive process of their own living in marginalized neighborhoods, might there be emancipatory potential in this embodiment?

\section{The Lessons of the City}

According to Shelley, 80 percent of what Mission Year participants learn is taught to them by the city, including, most importantly, by their neighbors. Nonetheless, the Mission Year program includes an extensive curriculum, in which participants read about the hard realities of American society, including, for example, racism and suburbanization, the embeddedness of racism or individuality in the typical American Christian church, and how these forces have contributed to oppression, such as the isolation of people of color from economic opportunities. This book learning takes place while participants have recently left the comfort of their own familiar social and spatial contexts for that of inner city poor residents who, in the case of Atlanta, are predominantly black. Shelley calls it "deconstructing their ideas about things," since most people, she suggests, "live in obscurity because we do not want to see." This is a central tenet of the program because, although applicants and recruits to the Mission Year program are expressly service-oriented Christians who state that they seek to help others, they are quickly challenged on what "help" means. Shelley explains that

Probably the majority of people still come to Mission Year because they want to do good things or they want to be a good person and share Jesus's love. But the reality of most of the motivation of that, when you read through people's application forms, is this privilege that they, most of the team members, live in before they get here. (Interview, 2012)

The program explicitly aims to problematize the power relation between giver and receiver in enacting agape love, which, we suggest, follows Wolterstorff's conceptualization of care-agapism in that it involves attending to injustice. Mission Year participants are largely stripped of their material wealth (with a limited budget for food and household maintenance) and encouraged over time to develop reciprocal relationships with their neighbors. Shelley shared that many participants come to Mission Year with a "savior mentality" and the idea that "I have it together and I can help you get it together if you conform to the way that I think you should." Given this 
common disposition among applicants, one function of the curriculum is to create in participants a more complex understanding of American society and of how social structures have influenced the way participants perceive society, church, the economy, politics, and themselves, but also how these perceptions have contributed to the oppression of others. The emphasis here on the relationality between individuals and social systems reflects a more complex reading of agape love than that dismissed by scholars such as Arendt.

We focus on one key piece of the curriculum to demonstrate the complexity of the social application of the agape love that Mission Year participants experience. As noted by the city director, Mission Year is committed to exposing participants to the role of racism in American society and as such developed its curriculum around important conceptualizations of race and the historical legacy of racism. For example, in the documentary Race: The Power of Illusion, episode three, entitled "The House We Live In" (Pounder et al, 2003) Mission Year participants learn that race is not biological, but is rather embedded in society, the political system, and the economy. The documentary exposes participants to the history of housing segregation as expressed in redlining (demarcating the areas of city maps where nonwhites live and determining those nonwhite residents ineligible for services such as federally-insured mortgages) and the "whites only" component to FHA loans (the federal government encouraged banks to lend to white people by providing insurance for the loan). These federal policies allowed white households to begin wealth building through homeownership, while offering other groups no such advantages (see Jackson (1985), Sugrue (2005) and Rothstein (2017) for scholarly discussions of the short- and long-term impacts of redlining in American cities). Shelley commented that the information in this documentary always really "tears people apart" because they never knew about the racism embedded in housing policies and their profound consequences on the continued wealth disparities between white and non-white households.

Discovering this housing history presents participants with evidence of "white privilege" (Tatum, 1997), which, for many, is their first exposure to the concept and to the consequences of the structural advantages enjoyed by whites. The documentary concurs with other texts selected by Mission year, such as Rah's (2009) point that whites create the standards for their own success and others' failure, yet, this is not solely a twentieth or twenty-first century problem :

The American economy was built upon free land stolen from the Native American community, and free labor kidnapped from Africa. Our current economic success owes a large debt to an initial economic foundation built upon free land and free labor. If we live as financial beneficiaries in the twenty-first century of this system of injustice, we have a corporate culpability and responsibility, even as we claim innocence in our personal, individual lives. (Rah, 2009, 71)

The Mission Year literature suggests that change has not gone far enough in the United States, particularly considering, as Shelley noted, that many whites are unaware of their privilege. Yet, Tatum informs participants that change will only go far enough when people become actively anti-racist. She compares ongoing racism to moving on an airport conveyor belt :

Active racist behavior is equivalent to walking fast on the conveyor belt. The person engaged in active racist behavior has identified with the ideology of White supremacy and is moving with it. Passive racist behavior is equivalent to standing still on the walkway. No overt effort is being made, but the conveyor belt moves the bystanders along to the same destination as those who are actively walking. Some 
of the bystanders may feel the motion of the conveyor belt, see the active racists ahead of them, and choose to turn around, unwilling to go to the same destination as the White supremacists. But unless they are walking actively in the opposite direction at a speed faster than the conveyor belt-unless they are actively antiracist-they will find themselves carried along with the others [...] [T] he relevant question is not whether all Whites are racist, but how we can move more White people from a position of active or passive racism to one of active antiracism? The task of interrupting racism is obviously not the task of Whites alone. But the fact of White privilege means that Whites have greater access to the societal institutions in need of transformation. To whom much is given, much is required. (Tatum, 1997, 11-12)

Indeed, one of the major goals of the Mission Year program is the realization of John Perkins's writings on racial reconciliation which, for him, begins with the scriptures. The very nature of God, as a triune entity encompassed in the father, the son and the holy spirit, is evidence of what Woodley names "unity in diversity." He argues that since God created the world according to his own nature, the nature of the world and everything in it is meant, by design, to be diverse, yet unified. A unified but diverse pattern can be seen throughout all of creation. Woodley calls attention to the variety of birds, trees, animals and humans with their various "moods" during different seasons. He asserts, "God has set us in a very diverse world-but it functions in perfect unity" (Woodley 38).

From this text, we see the focus on what most Christians would agree is a basic foundational truth : that all humans were created in the image of God. Rah explains the precise meaning of the term, "...the image of God means that "we could search the world over, but we could not find a man so low, so degraded, or so far below the social, economic, and moral norms that we have established for ourselves that he had not been created in the image of God." $(2009,82)$ The curriculum draws from biblical teachings and makes clear that all people, regardless of ethnic or cultural difference, are created in the image of God and deserve the same respect and dignity afforded any human on earth.

In Chapter 6 of Restoring At-Risk Communities, Spencer Perkins, who is black, and Chris Rice, who is white, present some of the challenges associated with racial reconciliation. S. Perkins explains that,

Blacks easily talk about what's wrong with White Folks and are understandably concerned about racial discrimination. But we are often reluctant to forgive and begin to trust. Sometimes we even use race as a weapon to keep Whites at bay. But while minorities are very concerned about racial justice, we are not-to the surprise of many White Christians-very interested in being reconciled. (Perkins, 1996, 121)

For Perkins reconciliation is a struggle for blacks, as they have experienced "bitter encounters" with racism. As an advocate of the three-R philosophy, he urges people to overcome their anger and bitterness by adopting forgiveness. However, Rice describes that,

As the majority culture, [whites] don't have to deal with race. We say "I don't see color," but the reality is that we don't have to see color. I can walk away from VOC [Voice of Calvary ministry] and Black people and the whole mess of race anytime I like. I can cross town tomorrow and enter the White world and know I will be treated well and not be denied opportunities because of my color. But my Black friends don't have that option. (Perkins, 1996, 117) 
points out the spatialization of privilege, wherein living in the "white world" means being able to ignore race, but blacks have no space in which to escape their marginalization in American society.

Taken as a whole, the curriculum's message about racism is multilayered, designed to uncover the often-hidden existence of institutionalized racism and white privilege and to charge individuals with the responsibility to become actively anti-racist. For example, participants learn that on a secular level, whites gain economically from the system built on stolen land and free labor, and second, it is against God's teachings to participate in a system that oppresses others. And, as Perkins and Rice suggest, addressing racism is hard work.

As most of Mission Year participants are white, and certainly all have experienced some privilege, intentional neighbors living and working in an area of high crime and violence means that often, besides their close neighbors, they may not be liked or trusted by other residents. Being unwelcome in particular spaces of the city involves the necessary challenge posed by embodiment. In fact, Bart expressed that for new team members there is

.... huge hurdle to overcome, assuming a team member is white and they're coming into a neighborhood that is mostly African American. Automatically there is a builtin level of mistrust, and in order to overcome that, it requires a person to be exceptionally humble, and patient. And that's not easy because a lot of our team members haven't had to do that. Because they are mostly young people of privilege. (Interview, 2012)

Overwhelmingly, prior to the program, most of the Mission Year participants lived in what they described as "a bubble," where they believed racism no longer existed. Removing their bodies from their bubble made them confront the realities of racism in the city. Certainly, even fewer were aware of their own privilege accrued to them based on class and racialized identity. Heather expressed that

It's really sad. Before I came to Atlanta I had no idea [about racism]. I had read about it in the history books, but I had no idea how extensive the racial tension still is today. When I was growing up we read about the Civil Rights Movement and the marches, and I had an idealized view that people started living next to each other and being friends. I didn't know [the reality]. (Interview, 2012)

Heather could read about Civil Rights from a distance and believe that significant social progress had been made. But it was not until she placed herself in a marginalized neighborhood of Atlanta that she could understand ongoing racial tensions.

While Heather understood racism's past through history books, some Mission Year participants stated that they had not thought about racism at all. Lillian shared that

Mission Year has made me think about race relations in a whole different way because, well, I never really thought about it, I guess. I knew about the Civil Rights Movement and all, but I never had a relationship with someone who wasn't my same race because the opportunity wasn't there. When I'd hear about race relations and politics I was like, I don't know, it really doesn't matter that much to me. But now it's a whole different thing. (Interview, 2012)

The same was true for John, who confided

I never really thought about racism before this year, you know, how it impacts and how it is embedded into the system. Where I lived was mainly white and it wasn't that big of a thing and not really talked about. I never really even thought about it. And now I'm like 'Whoa! It's embedded, and I've never seen this before. How could I not have seen this before? ! (Interview, 2012)

Transatlantica, 1 | 2017 
By embedding himself in a non-white neighborhood, John could see and experience the workings of racism. Debbie remembered, "I totally saw gay rights or gender roles, but racism? I thought we were equal" (interview, 2012). As the Mission Year participants confirmed, it does not, however, take very long living among inner-city residents in Atlanta before a person of privilege can more fully grasp racism's legacy.

Mission Year did not necessarily make participants aware that racism is wrong (as presumably they knew that) but, rather, experiencing their daily lives in the program showed them where and how racism still functions in society and how to question their own complicity in it, as Tatum's conveyor belt analogy suggests. Jen revealed her new understanding of her obligations : "If you're not saying anything, if you're not actively being racist but you're going with the crowd and you're not fighting against it, you are still a part [...] You have to actively push against it, fight against what's going on (interview, 2012). Similarly, Joe argues that,

There is a dramatic inequality in our society at the starting blocks. When you look at the neighborhoods and the education and the investment, at the start, there is just a giant gap. So you have a large group of people who are starting at a massive disadvantage. So for me social justice is trying to combat oppression and the logic in our society that chooses to argue that we are a post-racial society [...] we still have to be vigilant in fighting [racism]. (Interview, 2012)

James, who before the Mission Year program attributed poverty to individual pathology and poor decision-making, admitted to changing his thinking rather dramatically,

I think almost everything stems from racism. For poverty, it's the racism. I feel like racism is the umbrella word for everything else. Like, why are there no jobs? Racism. Why does the education system suck? Racism. I feel like I understood it more once I got to Mission Year. There was always kind of this hint of it, but I was exposed to and really understood why this is the way it is once I got to Mission Year. You can't really escape it in this program: you're living in it and always experiencing it. (Interview 2012, italics added)

41 Living in racism by living in a marginalized neighborhood changed James's mind about the perniciousness of racist processes and outcomes. The placement of James's body as a white male in a racialized neighborhood of the U.S. South offered him the opportunity to understand the depths of racism in contemporary American society.

Even more obscure than the sometimes-hidden impacts of racist policy is the concept of white privilege. In fact, Mission Year staff member Bart explains that when most of the new team members first enter these neighborhoods, they struggle with the mistrust that people have toward them because "they are mostly young people of privilege and they've been able to operate freely under the assumption that 'everybody knows me and everybody trusts me"' (interview, 2012). For example, James expressed the processing of his whiteness, as he became aware of white privilege when he moved into the unique situation in the Mission Year house :

It is three white males and four women of color and so being submerged into a house like that, while living intentionally and also reading books on racism, you almost have these feelings of guilt, like "oh crap, I'm white and I'm a man. I'm heterosexual and a Christian! Man, it's all going bad" But it really made me think about what it is like to be a white person because I never had to think about that before. (Interview, 2012) 
Not only was James experiencing his whiteness in the predominantly black neighborhood, but he also experienced his whiteness in the Mission Year home he shared with other residents of color.

Participants continue to grapple with their privilege and revise their understanding of their achievements because of where they live and the experiences their embodiment offers them. For example, Debbie commented that, "I look at things in the past and I'm like, 'oh, that wasn't luck, that was white privilege"' (interview, 2012). Coming to terms with their own complicity in racial oppression was challenging, as Shelley knew it would be for the participants. James admitted that, "at times it can be hard to love people and you get these judgmental ideas. It's really hard, and I need a lot of grace for it-from my faith and asking God to help me love people and especially serving in an under-resourced and poor neighborhood." Jen shared one of her experiences :

I mean I stand out [because I'm white and I live in a predominantly black neighborhood], and I've felt the stares and I've felt the glances and glares, I know. It's difficult for me. One time I got off the bus and I just started crying, I was like, "what have I done? I've done nothing, I don't deserve this" [...] They have been severely oppressed by people of my color and so they don't trust me, and they see me as this bad person because of what I look like. (Interview 2012)

Jen's experience as a white person living daily life in a non-white space, answering the call to live among the poor, changed her understanding of her own whiteness and privilege.

The readings on racism and privilege were a critical piece of the Mission Year curriculum, and the experiences of the participants living in high-poverty neighborhoods were transformational for them. In fact, it is this transformational potential that we see as distinguishing this expression of care-agape love from that dismissed by political theorists and philosophers as inward-facing, private, or, to use Arendt's words antipolitical. Through their embodied experiences, many of the young, privileged Mission Year participants recognized sociospatial structures as oppressive and developed an awareness of their own complicity in them.

\section{Conclusions}

At the outset of this paper, we offered Kageyama's "lovable city"-the one with a piano on the street corner and skate and dog parks-as a provocation to think about what love could do in and for the city. The love invoked in Kageyama's city is one of attachment to a place, a love motivating the creation of urban spaces of consumption for upper and middle-class residents (see also Florida, 2002). In contrast, the love motivating intentional neighbors is one of care and justice, a love motivating the creation of beloved community, in which the marginalized, excluded, and oppressed begin to flourish. This, we argue, is the love Mission Year participants seek to practice as they spend a year in a disinvested neighborhood forming relationships and sharing experiences with those neglected and deprived by and in the city. The social and spatial application of agape love, wherein intentional neighbors relocate to live in relationship with those they seek to love shifts their experience from one of private, selfless love to that of care-agapism, as Wolterstorff names it. They engage not just with their neighbors through deliberate encounters (see Walter et al., 2017), such as Saturday night meals in the Mission Year house, but also with the social institutions and 
structures that oppress their neighbors. This deliberate sociospatial re-positioning yields a transformation in their political subjectivities, as their placement in the inner city and their embodied experience of daily life disrupts what they knew about injustice in the city.

Our evidence suggests that many intentional neighbors develop a structural and relational understanding of white privilege and poverty that appreciates not only the role of larger social forces, such as institutionalized racism, but connects the typicallyunacknowledged privileges of white, middle-class people to the limited opportunities and multiple oppressions faced by their new neighbors. For many of the participants, what was awakened in them is the cultivation of human agency that King called for when he described building the beloved community by standing up to and opposing oppressors and oppression through agape love (King, 1957). According to Marsh (2005, 176), the three-R strategy "charted a new course for building beloved community in America-one that defied conventional political categories." And for us, intentional neighboring offers possibilities for political engagement in addressing injustice in the inner city, in creating the loving, as opposed to lovable, city.

\section{BIBLIOGRAPHY}

ARENDT, Hannah. The Human Condition. Chicago : University of Chicago Press, 1958.

---. On Revolution. Harmondsworth : Penguin Books, 1965.

BRENNER, Neil and Nik THEODORE. "Cities and the Geographies of 'Actually Existing Neoliberalism'." Spaces of Neoliberalism : Urban Restructuring in North America and Western Europe, edited by Neil BRENNER and Nik THEODORE, Oxford : Blackwell, 2002, 2-32.

CHIBA, Shin. "Hannah Arendt on Love and the Political : Love, Friendship, and Citizenship." The Review of Politics, vol. 57, no. 3, 1995, 505-535.

DEFILIPPIS, James. Unmaking Goliath : Community Control in the Face of Global Capital. New York : Routledge, 2004.

---, Robert FISHER and Eric SHRAGGE. Contesting Community: The Limits and Potential of Local Organizing, New Brunswick, NJ : Rutgers UP, 2010.

FAINSTEIN, Susan. The Just City. New York : Cornell UP, 2010.

FLORIDA, Richard. The Rise of the Creative Class : and How it's Transforming Work, Leisure, Community and Everyday Life. New York, NY : Basic Books, 2003.

FRASER, James. "Beyond Gentrification : Mobilizing Communities and Claiming Space." Urban Geography, vol. 25, no. 5, 2004, 437-457.

GORNIK, Mark. To Live in Peace : Biblical Faith and the Changing Inner City. Grand Rapids, MI : William B. Eerdmans Publishing Company, 2002.

HANKINS, Katherine. "Creative Democracy and the Quiet Politics of the Everyday." Urban Geography, vol. 38, 2017, 502-506. 
---, and Andy WALTER. “'Gentrification with Justice’ : An Urban Ministry Collective and the Practice of Place-making in Atlanta's Inner City Neighborhoods." Urban Studies, vol. 49, no. 7, 2012, 1507-1526.

---, Andy WALTER, and Kate DERICKSON. “'Committing to a Place' : The Place-based, Faith-based Legacies of the Civil Rights Movement." The Legacies of the U.S. Civil Rights Act, Fifty Years On, edited by Caroline NAGEL, Political Geography, vol. 48, 2015, 159-168.

HERN, Matt. What a City is For : Remaking the Politics of Displacement. Boston, MA : MIT Press, 2016.

INWOOD, Joshua. "Contested Memory in the Birthplace of a King : A Case Study of Auburn Avenue and the Martin Luther King, Jr. National Park." Cultural Geographies, vol. 16, no.1, 2009, 87-109.

JACKSON, Kenneth. Crabgrass Frontier : The Suburbanization of the United States. New York and Oxford : Oxford UP, 1985.

KAGEYAMA, Peter. For the Love of Cities : The Love Affair Between People and their Places. St. Petersburg, FL : Creative Cities Publications, 2011.

KING, Martin Luther, Jr. “Loving Your Enemies.” Sermon Delivered at Dexter Avenue Baptist Church, 17 Nov. 1957. kingencyclopedia.stanford.edu/encyclopedia/documentsentry/ doc_loving_your_enemies.1.html. Accessed 13 June 2017.

LAWSON, Victoria and Sarah ELWOOD. Relational Poverty Politics : Forms, Struggles, and Possibilities. Athens, GA : University of Georgia Press, 2018.

LEPOFSKY, Jonathan and James FRASER. "Building Community Citizens : Claiming the Right to Place-making in the City." Urban Studies, vol. 40, no. 1, 2003, 127-142.

LEWIS, C.S. The Four Loves. New York : Harcourt, Brace, 1960.

MARCUSE, Peter, and al., editors. Searching for the Just City : Debates in Urban Theory and Practice. London and New York : Routledge, 2009.

MARSH, Charles. The Beloved Community: How Faith Shapes Social Justice, from the Civil Rights Movement to Today. New York : Basic Books, 2005.

---, and John PERKINS. Welcoming Justice : God's Movement Toward Beloved Community. Downers Grove, IL : Intervarsity Press, 2009.

MARTIN, Deborah. “Enacting Neighborhood.” Urban Geography, vol. 24, no. 5, 2002a, 361-385.

---. “Constructing the 'Neighborhood Sphere' : Gender and Community Organizing." Gender, Place and Culture, vol. 9, no. 4, 2002b, 333-350.

MASSEY, Doreen. For Space. London : Sage Publications, 2005.

MCCANN, Eugene. "Inequality and politics in the creative city-region : Questions of livability and state strategy.” The international Journal of Urban and Regional Change, vol. 31, 2007, 188-196.

OAKLEY, Deirdre and James FRASER. "U.S. Public Housing Transformations and Housing Publics Lost in Transition." City and Community, vol. 15, no. 4, 2016, 349-366.

PALM, Risa. "The Role of Real Estate Agents as Information Mediators in Two American Cities." Geografiska Annaler Series B, Human Geography, vol. 58, no. 1, 1976, 28-41.

PERKINS, John, editor. Restoring At-Risk Communities : Doing It Together and Doing It Right. Grand Rapids, MI : Baker Books, 1996.

---. With Justice for All : A Strategy for Community Development. Venture, CA : Regal, 2007. 
PIERCE, Joseph, Deborah MARTIN, and James MURPHY. "Relational Place-making : The Networked Politics of Place." Transactions of the Institute of British Geographers NS, vol. 36, no.1, 2011, 54-70.

POUNDER, C.C., Larry ADELMAN, Jean CHANG, Christine HERBES-SOMMERS, Tracy Heather STRAIN, Llewellyn SMITH, Claudio RAGAZZI. Race : The Power of an Illusion (film). Independent Television Service, Ford Foundation, Corporation for Public Broadcasting, San Francisco, California Newsreel, 2003.

RAH, Soong-Chan. The Next Evangelicalism : Freeing the Church from Western Cultural Captivity. Downers Grove, IL : Intervarsity Press, 2009.

ROTHSTEIN, Richard. The Color of Law : A Forgotten History of How Our Government Segregated America. New York, NY : W.W. Norton and Company, 2017.

RUTHESIER, Charles. Imagineering Atlanta : The Politics of Place in the City of Dreams. New York: Verso Books, 1996.

SOJA, Edward. Seeking Spatial Justice. Minneapolis, MN : University of Minnesota Press, 2010.

STONE, Clarence. Regime Politics : Governing Atlanta, 1946-1988. Lawrence, KS : University Press of Kansas, 1989.

SUGRUE, Thomas. The Origins of the Urban Crisis : Race and Inequality in Postwar Detroit. Princeton and Oxford : Princeton UP, 2005.

TATUM, Beverly Daniel. Why Are All the Black Kids Sitting Together in the Cafeteria : And Other Conversations about Race. New York : Basic Books, 1997.

VALE, Lawrence. Purging the Poorest : Public Housing and the Design Politics of Twice-cleared Communities. Chicago and London : University of Chicago Press, 2013.

WALTER, Andy, Katherine HANKINS, and Samuel NOWAK. "The Spatial Solidarity of Intentional Neighboring." Place, Diversity and Solidarity, edited by Stijn OOSTERLYNCK, et al., Oxon and New York : Routledge, 2017, 109-126.

"Who We Are," 2017. Mission Year Website. missionyear.org/who-we-are, Accessed 13 March 2017.

WOLTERSTORFF, Nicholas. Until Justice and Peace Embrace. Grand Rapids, MI : Eerdmans Publishing, 1983.

---. Justice in Love. Grand Rapids, MI : Eerdmans Publishing, 2011.

WOODLEY, Randy. Living in Color : Embracing God's Passion for Diversity. Ada, MI : Chosen Books, 2001.

YOUNG, Iris Marion. Inclusion and Democracy. New York : Oxford UP, 2000.

ZITCER, Andrew and Robert LAKE. "Love as a Planning Method." Planning Theory \& Practice, vol. 13, no. 4, 2012, 606-608.

\section{NOTES}

1. We recognize that intentional neighbors and those associated with Christian community development follow a well-worn path among evangelical movements to renounce material wealth to ally with the poor. Movements have taken place in different Christian denominations across space and time, in places such as France and Italy in the $12^{\text {th }}$ and $13^{\text {th }}$ centuries, the 
settlement house movement in the United States and the United Kingdom in the early $20^{\text {th }}$ century, and liberation theology in Latin and South America in the mid- $20^{\text {th }}$ century. This variant traces roots to the experiences of Christian activists involved in the broader racial justice and feminist streams of the broader civil rights movement in the United States during the 1950s to the early 1970 s.

2. Women receive $\$ 10$ more per month to offset the cost of feminine products.

3. We include a description of the participants' home neighborhood setting to highlight the different geographical contexts from which participants arrive to an inner-city, predominantly black neighborhood in Atlanta, Georgia. And while we do not problematize the intersectional nature of identity in this brief table, we elaborate in more detail in the text that follows ways in which participants' positionalities vis-à-vis race and class in particular emerge for them in their Mission Year experience.

\section{ABSTRACTS}

In many American cities, middle-class, faith-motivated individuals and families are moving into poor, inner-city neighborhoods to live out their vision of social justice in the city by becoming "intentional neighbors." Drawing from the commandment to "love thy neighbor," these faithmotivated actors develop relationships with their neighbors and share their resources in order to work towards the transformation of these places. In this paper we use the case study of participants in Mission Year, a Christian community-development organization, to examine the spatial and embodied practices that are integral to "doing justice" and demonstrating love in the inner city.

Dans de nombreuses villes américaines, des individus et des familles issus de la classe moyenne, motivés par leur foi, emménagent dans les quartiers pauvres du centre-ville pour mettre en pratique leur idéal de justice sociale en devenant des "voisins volontaires ». Inspirés par le commandement "tu aimeras ton prochain comme toi-même", ces citoyens motivés par la foi développent des relations avec leurs voisins et partagent leurs ressources afin d'œuvrer à la transformation de ces lieux de vie. Cet article est une étude de cas des membres de Mission Year, une organisation chrétienne de développement communautaire. Cette étude nous permet d'examiner les pratiques spatiales et concrètes qui font partie intégrante du «faire justice » dans les centres-villes.

INDEX

Mots-clés: social justice, love, American city, faith, beloved community, neighboring

\section{AUTHORS}

\section{KATHERINE HANKINS}

Georgia State University 


\section{ANDY WALTER}

University of West Georgia

TRACI DAHL

Georgia State University 